\title{
Hepatitis C Virus Protease Inhibitors
}

\section{Patent Highlight}

\author{
Ahmed F. Abdel-Magid*
}

Therachem Research Medilab (India) Pvt. Ltd., Jaipur, India

Title:

Patent Application Number:

Priority Application:

Inventors:

Assignee Company:

Disease Area:

Summary:

Important Compound Classes:
Hepatitis C Inhibitor Compounds

WO 2012/019299 Al Publication Date:

US $61 / 372,575$

Priority Date:

Edwards, P. J.; Leblanc, M.; Moreau, B.

Boehringer Ingelheim International $\mathrm{GmbH}$

Hepatitis C Virus

Biological Target:
February 16, 2012

August 11, 2010

\section{Infection}

Hepatitis C Virus (HCV) NS3 Protease

The invention in this patent application relates to the compounds represented by Formula (I). The novel compounds of Formula (I) possess potent activities against the NS3 protease encoded by hepatitis C virus (HCV) and have shown activities as inhibitors in a cell-25-based HCV replication assay. Chronic HCV infection affects nearly 170 million patients worldwide and may lead to serious liver diseases such as cirrhosis and hepatocellular carcinoma over time.

The HCV-encoded NS3 protease is believed to be essential for the viral replication, and its inhibition has become an attractive target to attack the virus and treat the diseases associated with its infections. The use of NS3 protease inhibitors is a new innovative therapeutic approach that directly attacks the hepatitis $\mathrm{C}$ virus and can offer effective treatment for its serious long-term effects in infected patients.

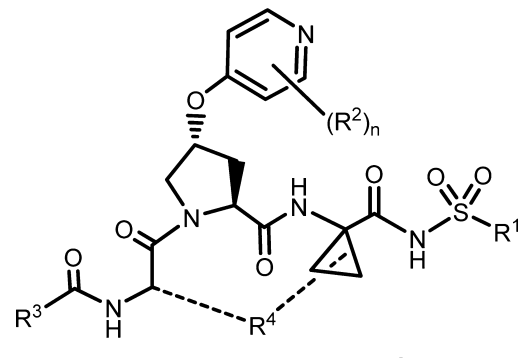

Formula (I)

Two representative examples reported in the patent application are designated as compounds 1002 and 3001:
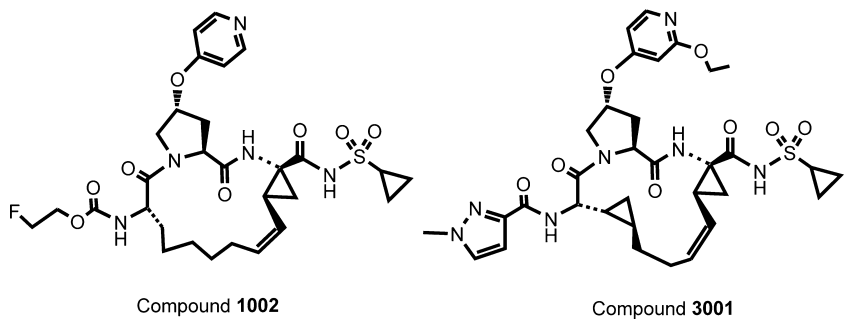

The two compounds were tested in two different assays:

\begin{tabular}{|l|l|l|}
\hline Compound & $\mathbf{E C}_{\mathbf{5 0}}(\mathbf{n M})$ & Assay \\
\hline 1002 & 290 & Cell-based luciferase reporter HCV RNA Replication Assay \\
\hline 3001 & 34 & HCVSPF-CY1B assay \\
\hline
\end{tabular}


Recent Review Articles:

Additional Information:
Thompson, A. J.; Locarnini, S. A.; Beard, M. R. Curr. Opin. Virol. 2011, 1 (6), 599-606.

Meanwell, N. A.; Belema, M. Annu. Rep. Med. Chem. 2011, 46, 263-282.

Foote, B. S.; Spooner, L. M.; Belliveau, P. P. Ann. Pharmacother. 2011, 45 (9), 1085-1093.

Chen, K. X.; Njoroge, F. G. Hepatitis C; Tan, S.-L., He, Y., Eds.; Caister Academic Press: Norwich, UK, CODEN:69OLB5 ISBN: 978-1-904455-78-3, 2011; pp 169-192.

The word hepatitis means swelling and inflammation of the liver. The infection with hepatitis $\mathrm{C}$ virus is the leading cause of hepatitis. Nearly 3-4 million people in the United States and 170 million globally have chronic hepatitis $\mathrm{C}$ infections. Most of the patients do not develop any symptoms and may not know that they are infected, while the virus could be causing damage to their livers and may lead to serious consequences over time before it is detected.

In the late 1980s, the combination of pegylated interferon and ribavirin (believed to act by stimulating the immune system) became the standard treatment for hepatitis $\mathrm{C}$ infections. While effective, it suffered from limited scope as it does not cure all patients with genotype 1 virus. Additionally, interferon causes very severe adverse effects that are intolerable to many patients. In 2011, a new advancement in treating HCV was realized by approving two antiviral direct acting drugs: Boceprevir (trade name Victrelis) developed by Merck and Telaprevir (trade names Incivek and Incivo) codeveloped by Vertex and Johnson \& Johnson. These drugs are $\mathrm{HCV}$ protease inhibitors that unlike interferon, target the virus directly and slow its replication. However, these drugs are still used in a triple combination with interferon and ribavirin. While the introduction of these drugs is a significant leap and considerably superior treatment as compared to previous treatments, it does not treat all types of $\mathrm{HCV}$, and patients still have to deal with the serious intolerable adverse effects of interferon.

The research in this field is progressing fast; the next generation HCV protease inhibitor drugs are aiming to work alone to eliminate the use of interferon and to expand the scope of the treatment to include all types of $\mathrm{HCV}$ infections. Currently, there are several experimental drugs in development that show great promise of achieving these goals; some of these experimental drugs are listed in the following table:

\begin{tabular}{|l|l|}
\hline Experimental Drug & Developing Company \\
\hline Danoprevir (a.k.a. RG-7227 and ITMN-191) & Roche \\
\hline TMC-435 & Medivir AB and Janssen \\
\hline ABT-450 & Abbott \\
\hline ACH-1625 & Achillion \\
\hline $\begin{array}{l}\text { Daclatasvir + Asunaprevir (a.k.a. BMS-790052 + BMS- } \\
\text { 650032) combination }\end{array}$ & Bristol-Myers Squibb \\
\hline Bl-201335 & Boehringer Ingelheim \\
\hline
\end{tabular}

\section{AUTHOR INFORMATION}

\section{Corresponding Author}

*Address: 1383 Jasper Drive, Ambler, Pennsylvania, 19002,

United States. Tel: 215-913-7202. E-mail: afmagid@comcast.net.

Notes

The authors declare no competing financial interest. 